\title{
Economic and monetary consequences of Lebanese National debt
}

\author{
Youssef Hussein Abdulkhalek ${ }^{1}$ * \\ ${ }^{1}$ Lebanese International University, Lebanon \\ *Corresponding author: Youssef Hussein Abdulkhalek: youssif_ak@hotmail.com
}

\section{OPEN ACCESS}

Citation: Abdulkhalek Y.H. (2017) Economic and monetary consequences of Lebanese National debt. Open Science Journal 2(4)

Received: $5^{\text {th }}$ June 2017

Accepted: $25^{\text {th }}$ August 2017

Published: $13^{\text {th }}$ October 2017

Copyright: (C) 2016 This is an open access article under the terms of the Creative Commons Attribution License, which permits unrestricted use, distribution, and reproduction in any medium, provided the original author and source are credited.

Funding: The author(s) received no specific funding for this work

Competing Interests: The author have declared that no competing interests exists.

\section{Abstract:}

The Lebanese financial condition is miserable. The national debt to GDP is increasing to horrible levels, and the deficits in government is increasing and expected to increase in the subsequent years, the government spending is increasing without any deterrent in the time the revenues to the government are decreasing, the inflation rates are increasing and the economic growth is decreasing. The fallouts of these conditions have direct effect on Lebanese pound and threaten its value. With all the assures from Lebanese central bank governor and the financial officers, a prudent man can sense the risk that is coming on the Lebanese pound and never believe that the Lebanese pound will stay forever the mountain that never lean with wind. Lebanon must take rapid corrective actions to save the country and its currency from a disaster that would howl.

Corrective actions of economic, financial, political, and direct reforms must studied and activate it directly before the zero time comes and remorse will not benefit.

Keywords: National debt to GDP, National deficit, Government spending, Gross domestic production, Central bank, International monetary fund, Government treasuries, Foreign reserve, Inflation, depreciation 


\section{Introduction}

Lebanon is one of the countries that are carrying a heavy national debt that is accelerating in fearful rates year after year. The problem of the national debt is not new in Lebanon it starts at the time of the civil war 1980s when the government increases it's spending on the military services and other public services and find no solution other than borrowing.

When the civil war finished in Lebanon in 1992 the national debt was 4,382 billion Lebanese pound most of it from the domestic market in the form of treasuries sold to the Lebanese commercial banks, after that time many regulations issued by consecutive governments to increase the ceiling of foreign debt giving them selves the legality to maximize the debt. This encouraged governments to increase the debt without deterrent and the debt reached 21,926 milliard Lebanese pounds in 1997, this means that the debt increased five times in five years. The national debt continued increasing until now days with horrible levels where it estimated to reach by the end of 2014 the 70 milliard dollars or about 105,000 milliard Lebanese pounds! These numbers were enough to classify Lebanon today from the first 10th countries in the world with highest national debt. This can still be digestive if the government is able to serve that national debt and pay its bills in full amount and on time, but if the government was not able to serve the debt this should be an alarm, that should awake the politicians and the economists to take rapped corrective action before the disaster howl.

The Lebanese monetary ministry after its study of the budget balance for 2014 found that the expected government budget deficit will be 7,669 milliard Lebanese pound (4,88 milliard dollars) which is about $25 \%$ increase of the deficit of 2013 which was 6,150 milliard Lebanese pound (4,1 milliard dollars). More over the budget deficit expected to be about $10.7 \%$ of the gross domestic product of 2014 , where it was no more than $9 \%$ of the gross domestic product of 2013 . In addition, the national spending expected to increase about $3 \%$ where the national income expected to increase only about $1 \%$ in 2014 . And the service of debt is expected to be 5,890 milliard pounds which is about $78 \%$ from the total deficit and this will be added to the national debt by the end of the year unless the government find a vent to pay it.

The inflation rates and the economic growth wasn't at a better state, the statistical central administration showed that the inflation rates in Lebanon increased 30.9\% from December 2007 until December 2013 knowing that the rate accelerated after 2012. Economically the conditions wasn't better since Lebanon decreased in its classification from the level 92 till the level 103 according to the international competitiveness report since from 2010 till now days the economic growth decreased from $8 \%$ to below than $1 \%$. We can never forget under all these pressures the domestic political uncertainty and the regional uncertainty that is negatively reflecting its effects on the domestic economy.

\section{Hypothesis based on current situation}

Under all these realities we still hear assures from politicians and financial leaders that the economic cycle is moving better, the international trust in the 
Lebanese monetary market is still high, the central bank is still having high flexibility to intervene in the market. And the most amazing thing that we hear that the Lebanese pound is stable and we should not fear about its stability.

Here is the question whether all these assures are true and we should believe, or we should look more deeply and think more logically about the economic and monetary state asking our selves how much Lebanon can hold more debt and how it can pay the service of that debt that is reaching horrible levels. Until when this can still be hold since we may believe these assures in the short term but we can never believe them on the long term. We should ask our selves what could happen if the conditions remain the same or even go more worse and what corrective actions we can take today before tomorrow to escape from a disaster that is coming closer day after day.

According to the international monetary fund (IMF), Lebanon has the 4thlevel internationally based on the size of the national debt with respect to its gross domestic product. When a country has a very high debt then each year it must repay high interests on that debt (service of debt), and the country will hold a great load each year especially if the country enters in a deficit when the spending exceeds the earnings of the government.

In this case, the country would not be able to repay its obligations and it simply will bankrupt on the long term or it will borrow additional funds to repay its current obligation to keep standing in the short term but this way is not a solution but a delaying of the crisis.

This is exactly the case of Lebanon, the national debt is increasing in a fearful rates and the government deficit is increasing since the national spending is increasing higher than the rate of increase in the national earnings (national spending expected to increase about $3 \%$ where the national income expected to increase only about $1 \%$ in 2014). Knowing that about $78 \%$ of the deficit is due to the service of debt, under this situation Lebanon will not be able to pay its obligations and the government will be closer to bankruptcy that's signs starts to appear.

The central bank insists under all the pressures and demonstrations in summer 2014 to do not pay the ranks and series of salaries to the teachers and the public sector and without any concern about the decision that taken from the educational ministry to give free testimonies for all students. Simply it sacrifices by the educational level and sector to keep certain monetary stability.

The financial minister of Lebanon declared in an interview to Alliwaa newspaper in 21 October 2014 that the financial and economic crisis in Lebanon is appearing large, but inside it, there are lots of secrets if disclosed the country may collapse! Spotting the light on the importance of creating a stable political environment to stimulate the economy and support the financial sector.

In 28th of same month the Lebanese financial ministry declared that there will be a delay in paying the salaries of December for the military forces from the 1st to 7th of December, knowing that it is the first time in Lebanon this happens and even in the civil war when Lebanon was in its worst conditions this didn't happened.

In addition, the central bank requests from government to issue new treasuries (euro bonds) with a face value of 1.5 milliard dollars to be used to pay portion of the service of debt that the Lebanese central bank will not be able to 
hold. The Lebanese government understands the pressures on the central bank, and it is finalizing the procedure of issuance.

\section{Government deficit and its domino effect on currency value}

These declarations confirm that we must wake up and start to take corrective actions in economic and financial sectors that need lot of corrections. These are few of many other signs that all confirm the miserable financial conditions that Lebanon facing and disclose a bankruptcy or a coming bankruptcy. The Lebanese central bank cannot always and each year issue treasuries to finance the service of its debt since this not allowed according to International Monetary Fund. Then in the following years, the central bank will find itself in front of complete deficit to finance its obligations if the economic conditions stay as it is or even deteriorates more as the expectations and the trends shows.

Under such situation, Lebanon will find no other way than printing more money to monetize its debt and pay its service, pay the salaries for the employees in the public sector, and pay for its imports. Then it prints Lebanese pounds and demands foreign currency to repay the foreign debt and pay for the imports; this way increases the supply of the Lebanese pound and increases the demand on foreign currency in the foreign exchange market.

This will increase the price of foreign currency relative to Lebanese pounds and thus it will depreciate the value of Lebanese pound in international market.

When the Lebanese pound depreciate so more Lebanese pounds are needed to purchase same amount of foreign currency so the Lebanese central bank need to issue more Lebanese pound and thus the currency will depreciate more and more. For sure the government will not be able to stop its imports that are necessities such as the fuel, petroleum, gas ..., since Lebanon is a country that imports $80 \%$ of its needs, so this process will be out of control the government continues printing currency and currency continues its depreciation.

More over the government needs funds to pay domestically as salaries for employees in public sector, pensions, supports for health, educational, social sectors ..., reconstruction, infrastructure, ..., .

If the government was in deficit and bankruptcy it must also print the money to satisfy its domestic operations, regardless whether the government has sufficient foreign reserve to back the process of printing more funds, this process will also increase more the supply of Lebanese pounds.

When the supply of funds increases the inflation that is now escalading in horrible levels (Inflation rates in Lebanon increased 30.9\% from December 2007 until December 2013 knowing that the rate accelerated after 2012) will turn unbearable and a monster that will crushes the purchasing power. When inflation increases the purchasing power of that currency decreases and thus the value of that currency will decrease or depreciate more, this is explained according to purchasing power parity theory in finance.

Central bank will not stand idly in these conditions, when the value of currency starts to depreciate it should work to keep the value of the Lebanese pound stable as it is fixed in its name value $1500 \mathrm{~L} . \mathrm{L} / 1 \$$. The central bank will 
find it self always under the pressures to intervene in the foreign exchange market and sells daily bulk of dollars to buy the Lebanese pounds trying to stimulate the demand on Lebanese pounds to stimulate its value. For example in 2005 after the murdering operation of Al-Hariri prime minister, the Lebanese central bank lost 1.5 milliard dollars when it sells them in the foreign exchange market to support the Lebanese pound. But the Lebanese central bank could not always intervene in the market even if it has a high reserve that it is proud of it which is about 160 milliard dollars that covers the GDP by about three times. Since this reserve is for depositors and investors, and it can't take risk in this reserve specially if the value of Lebanese pound is decreasing.

On the other side the central bank can also issue more treasuries and sell them domestically to the commercial banks that are overwhelmed by government treasuries to decrease the supply of the currency trying also to stimulate its value. The commercial banking sector in Lebanon merely stands beside the central bank and the government to decrease the national debt and support the government. In Paris conference two in 2002, the Lebanese commercial banking sector supports the Lebanese government in four milliard dollars by buying treasuries with zero Interest rates to decrease the national debt, and it was one of most important supports for Lebanon to decrease its national debt. But from 2002 till now days 2014 national debt increased from about thirty milliard dollars till about seventy milliard dollars!. Till when the commercial banking sector could still support the government and could it still trust the government with its heavy debt specially if the government deficits increased and bankrupted.

Under these situations, the central bank could do nothing, or to be more peaceful it may be able to intervene in foreign exchange market and domestic money market on the short term since it has a strong reserve for intervention that we can't ignore, or it can borrow additional debt. However, we can't say that this is the solution, it is just delaying a crisis that is incident.

In such conditions, the behavioral finance comes to play its role and make the situation worst. Some people who are risk averse will withdraw there funds from commercial banks and transfer them outside to more stable markets, since commercial banks invests in treasuries and any bankruptcy in government may affect the overall financial sector and will be just as a domino jumping to all sectors in the country. Other people may keep their funds in domestic market but switch their accounts to foreign currency. In both cases, many people will not be able to keep holding the Lebanese pounds, and this decreases the demand on Lebanese pound relative to the foreign currency making the Lebanese pound depreciate more.

Moreover, when the Lebanese pound will start to depreciate and the central bank will try to support its stability, there will be a fluctuation in the value of the Lebanese pound. This will encourage speculators to speculate on the currency value relative to the value of foreign currencies exactly as what happened in 1980s. The commercial banks themselves may stain their hands in speculation, to compensate any loss that may occur from deterioration in the value of treasuries that dominated in deteriorated currency (Lebanese pound).

All these realities and logical analysis confirm that Lebanese pound will never stay the mountain that never leans with wind if the conditions stay as it is without any correctives or improvements. Otherwise the case of Lebanon will not be much better from the case of Argentina that faced heavy debt and deficit 
reached about $10 \%$ of its GDP. Argentina finds no solution to pay its debt and buy its imports and serve its domestic public sectors other than printing money, this boosts the inflation that reached $12,000 \%$ per year and results in collapse of currency. Same thing happened in Bolivia where government revenues covered less than $15 \%$ of its spending in the time of very high debt that it was holding this ends with hipper inflation of $101,000 \%$ per year and collapse of currency.

\section{Current state of Lebanese pound compared to its state in 1980's}

These cases and conditions remained us by the nightmare of 1980s that Lebanon faced during the civil war when the Lebanese pound depreciated from about 3.3 Lebanese pounds per dollar at the beginning of 1980s to more than 3,000 Lebanese pounds per dollar at the beginning of 1990s. The Lebanese pounds that buy for you a condo in beginning of 1980s only buys you piece of cake in beginning of 1990s, that's why many people lost their wealth when the Lebanese pounds collapsed. The reasons for the collapse of the Lebanese pound at that time were in the first level the increase in the national debt and the national deficit. Government increases it's spending on military services and increases its printing for Lebanese pound to pay its obligations for domestic sector and to serve its debt in the time the revenue that enters the treasury were neglected compared to the spending. The national debt reached more than 14 milliard Lebanese pounds, which is less than four milliard dollars at that time. And the national deficit reached its highest levels at that time in 1984 but never reached the milliard dollars. Today we are taking about 70 milliard dollars in national debt and about 5 milliard dollars in government deficit, today and before tomorrow, corrective actions must taken to escape from a disaster which signs are being clear day after day.

\section{Solution to save the Lebanese pound before the disaster howls}

Government can issue bonds in order to use the proceeds to repay the service of debt and a portion of debt if the proceeds were enough to cover, and this is what Lebanon doing now. The parliament legislates an issuance of euro bonds with a face value of 1.5 milliard dollars to pay the service of its debt and cover the deficit that expected to be 5 milliard dollars. This can be just a solution on the short term but never be a solution on the long term since the government then has to pay interests and face values of the treasuries at maturities, so it is solving the problem by increasing the problem. It is very important for government to create a stable economic environment before issuing the bonds in order to be classified in a better credit rating to safe itself from paying higher interests on its higher risky bonds. The euro bonds that will be issued soon classified as junk bonds which is the level that is just before the classification of risky bonds, so central banks and government should play their role on ground to 
create the needed environment to rank the bonds to better levels or at least to do not deteriorate to lower ranks.

\section{Balancing the exports and imports}

The government deficit is mainly due to spending that is higher than earning, this means that imports plus the domestic spending higher than exports plus the taxes. To solve this problem according to this equation that known by the balance of payment equation, governments must boost the exports and taxes and cut the spending and the imports. In this way, the revenues to the government will be higher than spending, and the balance of payment will be positive and the government can repay its debt and no fear on the currency value on long term.

To boost the exports over the imports it is almost impossible because Lebanon imports necessities such as fuel, gas, petroleum, raw materials and others, and about $80 \%$ of the needs of Lebanese market are imported from outside.

Here comes the government role to encourage the industrial sector that is facing a lot in Lebanon, where the Lebanese industrials represent now days just $18 \%$ from the GDP in comparison to $27 \%$ from the GDP in 1999.

Knowing that the international market for the Lebanese products expand to Africa, Japan and Hon Kong, in addition to Arabian and European countries. This explains the absence of government role to encourage and support this industry since it is accepted and expanding internationally but on the ground it is retreating.

The government should take serious steps to encourage this sector by offering tax exemptions, lower interest rates on any borrowings for these sectors, legislating laws that protect the Lebanese industrial products and encourage professional education that is necessary to create the labor force that needed for such industries. In this way, I will not say that we can boost the exports over the imports but at least we can decrease the imports from $80 \%$ to $60 \%$ for example from our needs.

In addition, we cannot forget the agricultural sector that is the poorest and most ignored sector in Lebanon that represents no more than $10 \%$ from the GDP. Knowing that Lebanon has fertile soil and water that are the most important elements for agriculture, but the agricultural proceeds are deteriorating in the complete absence of governmental support.

The government can support it by giving low interest rate loan to back this sector, encourage the use of technology in agriculture, legislating laws that protect the Lebanese products, increase the tariff taxes on imported agricultural products since this product is elastic domestically and encourage professional education that is necessary to create the labor force that needed for this industries.

The government must rethink about the conditions of agriculture in Lebanon and support it and it must jettison the static thinking and be open for new agricultures. Hashish is one of agricultures in Lebanon that faced by government and public, but the hashish in Lebanon has the best quality worldwide and is used in medical productions. 
Thus, instead to damaging it and paying costs on its damaging programs, it can retain high proceeds for the government if exported. Moreover, the crocus which is the plant that is known by the red gold because it is scarce and expensive and also used in medical productions, recent studies showed that Lebanese soil is one of the best worldwide to plant crocus. People still unaware about the importance of this plant and many of them do not know the crocus, but our blame is not on those people but on the government that is doing no thing to not only encourage but also enforce such agricultures, because these agricultures will retain very high proceeds when exported to developed countries. The idea is not just to have petroleum to be rich country but the idea is to have minds.

The government should try to rebalance the sectors in Lebanon, so the sectors fairly distributed according to GDP, and decrease the weight of the service sector that represents more than $70 \%$ of the GDP. Since the service sector is a weak sector that sakes from any political or economic uncertainty that may appear in market. Lebanon is now more than before in need to have sectors that can't lean easily from any small uncertainty.

Insurance of these sectors can boost the exports and decrease the imports specially that are not in need. It is not necessarily to expect superior exports and great decrease in imports, but at least we can expect better level of exports and imports that can balance the balance of payment and decrease the deficit and thus protect better the value of the Lebanese pound.

\section{Managing spending and taxes}

After stimulating the exports, to minimize the national debt and reduce the national deficit. Lebanon move to the second step to cut the spending and increase the taxes, this is one of most effective ways to reach such goal and this is proved in Argentina and Bolivia cases that faced collapse of there currencies and hyperinflation reached to $12,000 \%$ and $101,000 \%$ respectively due to huge national debt in 1980s. The only solutions was following a strict austerity policies and spend only what they receive as revenues and after few months the inflation problem solved and the currency start to appreciate.

In Lebanon until now days even in the collapsible financial conditions due to the heavy national debt and the budget deficits that reaching horrible levels, the governments are not thinking about any austerity programs to be followed but even they are increasing the spending. This is because either politicians are unaware where this can reach us, or they are simply afraid to loose there people incubator and thus their chairs in parliament if they were courage and declare the need to start austerity programs. Since austerity causes social and economic fallouts on the short term but it proved its efficiency and effectiveness on the long term. Austerity is a need in Lebanon today before tomorrow to cut the spending and thus save enough to serve the national debt otherwise the condition will be miserable.

In addition to austerity programs, Lebanon can increase the taxes to increase the revenues to the treasury and decrease the national debt or at least be able to serve that debt. The increase in taxes is not necessarily to be the increase in VAT since it deteriorates directly the purchasing power of citizens, knowing that VAT 
$10 \%$ (value added taxes) in Lebanon is still much better than other Arab countries such as Jordan, Algeria, Tunisia and Morocco that reach 16\%, 17\%, $18 \%$ and $20 \%$ respectively. The increase in taxes can be on corporate tax on profit, tax on movable capital, property tax, stamps and custom duties. Moreover, increase taxes on specific products such as luxuries, Alcohols, all tobacco products, entertainments, new cars, luxury food,

This can keep balance between social layers and increase retains for government, knowing that this was a proposal to finance the ranks and salaries series for the public sector in summer 2014 but it didn't legislated because who will legislate it are the main ones who will burden the higher taxes!

\section{Learning from Greece national debt crises}

Without going so far lets learn from Greece trail in solving its national debt crisis in 2010. The problem is believed to have been directly caused by a combination of structural weaknesses of the Greek economy along with a decade long pre-existence of overly high structural deficits that increased from $5.5 \%$ in 2005 till $15.7 \%$ in 2009 as a percentage of GDP. The deficits were because the government spending was increasing about $70 \%$ in time the revenues were increasing no more than $30 \%$ and due to tax evasion and corruption, and debt-toGDP levels on public accounts increased from $100 \%$ in 2007 till $217 \%$ in 2013 . In late 2009, fears of a sovereign debt crisis developed among investors concerning Greece's ability to meet its debt obligations, due to a reported strong increase in government debt levels. This led to a crisis of confidence, indicated by a widening of bond yield spreads and the cost of risk insurance on credit default swaps compared to the other countries in the Euro zone, and classification of Greece bonds deteriorates to Junk bond. All this threats Greece to stay a member in the euro zone.

It was not easy for Greek to escape from its problem and when the case exacerbated on 2 May 2010, the Euro zone countries and the International Monetary Fund (IMF) agreed on a $€ 110$ billion bailout loan for Greece, conditional on compliance on three key points.

First conditional was implementation of austerity measures to restore the fiscal balance, this reached by cutting the spending and increasing the taxes, regardless on its fallouts on the Greece society from the increase in unemployment levels, decrease in per capita income, carrying heavy load due to high taxes and ..., this way proved its efficiency in rebalancing the budget balance.

Second conditional was privatization of government assets should be worth $€ 50$ bn by the end of 2015 , to retain enough funds to government and used to decrease the national debt that was over loaded.

Third conditional was implementation of outlined structural reforms, to improve competitiveness and growth prospects and stimulate the economic sectors and productivity, this can animates the exports and reduce imports to keep the balance of payment have some balance.

Greece worked hard under the pressures of the demonstrations and repeals of oppositions but over three years it start go out from its adversity. 
The case of Greece from 2005 till 2010 when the crisis starts appear clearly, dose not differ than the case of Lebanon now days, even I see that Lebanon is living the same conditions and passing the same crisis that Greece passed through. The weakness or even the freeze of the economy from more than 5 years, the accelerated rates of national debt to GDP, the increase in spending without deterrent and the decrease in revenues, the increase in government budget deficits and expectations to higher budget deficit in consecutive years. Moreover, the tax evasion, corruption, and inability of government to collect taxes effectively and the recent deterioration of Lebanese bonds credit rating to junk bonds. In addition to all this, Lebanon has more worse economic and political environment, more over when the Greece was in its crisis the European Union intervenes to rescue it because they were concerned about the euro that was threaten. The question here if Lebanon reached such crisis who will intervene and who will be concerned about the Lebanese pound?

\section{Privatization}

Other than boosting the exports, decreasing imports, rising taxes and cutting spending we can also think about privatization as a way to decrease the national debt, that also was a condition for Greece to rescue it from its crisis. The Lebanese economy is characterized by the sever intervention of government and the inexperience of the managers of its organizations. To make these organizations more effective and efficient privatization would be an appropriate solution that can rebalance the Lebanese economy, encourage investments and stimulate Beirut bourse.

Here we are taking about the sterilized privatization that is clear from monopoly and away from segmentation of the public sector for the politicians and subjected to effective monitoring and accountability.

Privatization had proved its efficiency in increasing the return to the government and thus decreasing the deficit in the developed countries such as the privatization in British, but it was no more than stealing the public sector in most developing countries. In Lebanon to make an efficient privatization we need basket of corrective actions to be made, starting from making an official financial market that is transparent, accountable and superintendence so that the issue to the private sector can be efficient and effective and proper prices can be set to underwrite the issuance of public organization to private sector. Knowing that in Lebanon there is a law that regulates this procedure but is still studied by the financial ministry from 1996 until now days! Moreover, we need corrective legislations that organize the privatization and define the responsibilities.

Lebanon privatized different sectors such as the cellular net work that privatized to MTC and Alfa companies. Regardless of the disadvantages of these companies and there monopolistic actions, they represent the second source of income for government. They bring about 1.5 milliard dollars with 4.2 million customers that are increasing each year. Moreover, Lebanon privatized collecting the public wastes to Sukleen Company that collects yearly about 1.5 millions of tons of solid wastes and only $10 \%$ recycled, knowing that $50 \%$ of them can be recycled so the government can use the remaining $40 \%$ to recycle to cover portion of the costs of the contracts with the company and thus decrease its costs. In 
addition, there is privatization of civil aviation to Middle East Company and other privatizations... Regardless of all repeals against privatization, these companies proved a higher efficiency, effectiveness, and return than when these sectors managed directly from government.

We can think of new privatizations, such as the privatization of electricity and water. The electricity sector is facing lot of difficulties and deterioration in its efficiency and great collapse in its organization, and it represents the second biggest source of spending for the government after the service of debt. From 5 milliard dollars of total deficit there is more than 1 milliard dollar deficit only from Lebanese electricity, one of most important reasons is the in ability of the government to force an effective collectivity program for collecting subscriptions. This can be solved in privatization by directly canceling the subscriptions for the violators and eliminating the possibility of stealing electricity lines. Other privatizations we can study such as privatization of water, public transportation, port ... if they can retain higher retain for government and sold for the private sector with high prices that can cover portion of the national debt.

In Arab countries, there was successful privatization for electricity sector such as in Jordan and Abu Dhabi city. Such privatization increases the returns to the government and increases the efficiency that reached in Jordan to $99 \%$, the privatization of electricity in Italy retains for government about 40 milliard dollars in 1990s, and in Abu Dhabi about 10 milliard dollars. These retain can simply be used to decrease the national debt that is overwhelming.

\section{Renewable energies forgotten opportunities}

Now days we can think about the renewable energies as a solution to produce the electric power instead keeping on importing the fuel that is too costly and the government is being day after the other unwilling to pay for its fuel imports, specially the demand on the kilowatts is increasing about $10 \%$ per year. Lebanon can never stop this import because it is a necessity and this is increasing the deficit and thus threatening the Lebanese pound on the long term.

Lebanon can start to think in more uplifting way, and think about using renewable recourses to produce electric power that is costing now days more than $20 \%$ of national deficit and it occupies the second largest spending source for the government after the service of debt.

The renewable resources that we can use are different and all can safe funds for the treasury and thus protect the Lebanese pound. First, we can depend on the hydropower since Lebanon is rich in water compared to the region and thus it can be easily applied.

In addition, we can use the wind power also to produce electric power, and studies showed that the Middle East region has active wind movements and thus it is an opportunity to Lebanon to benefit from wind power, specially Lebanon has 210 kilometers sea extent and has different reliefs that help also in making such project more effective and successful.

Moreover, we can't forget the solar energy that is being so effective in developed countries such as USA, Chain, Russia, Europe and it start to be effective in our country but in the solar heating but on private and individual level in complete absence of government to make real encouragement for this 
usage. Lebanon can benefit from such power because in Lebanon the average sun hours are more than 3,000 sun hour per year while the countries that are using this energy have an average of no more than 1,000 sun hour per year.

Lebanon with all these environmental opportunities to use the renewable resources starting from rich availability of water, active movement of winds, and the high availability of sun hours per year, Lebanon produce only $3 \%$ from its need of energy from renewable resources and the remaining $97 \%$ are imported by barging financial transaction. Its time to wake up, benefit from the opportunities around, and make a real shift in the using of renewable resources to produce our need of energy. Even if the previous government put a plan to increase the use of renewable resources to produce $10 \%$ energy of our need by the end of 2020 , this still make us shamed and such irreverence is not accepted. If the government is not able to increase its dependency more on the natural recourses, let it share this responsibility with the private sector by privatizing the projects, because this is capable to reduce more than $70 \%$ of the current cost of electric power that our government is not able to carry any more.

The $70 \%$ reduction in the cost of the fuel is capable to stimulate the balance of payment and thus decrease the pressures on Lebanese pound that is increasing day after the other.

\section{The new discovered treasures}

Under this section, we can talk about the new oil reserves that found in Lebanese water along its northern maritime boundary with Cyprus, Syria and Israel, which could generate billions of dollars.

Based on the survey that made by BGC a Norway's company there is about minimum 25 trillion feet square of gas and maximum 80 trillion, and about 1.5milliard barrel of oil. Knowing that each trillion feet square of gas valued by 12 milliard dollars, so wealth from gas will be minimum 300 milliard dollars and in maximum 960 milliard dollars, and the wealth from oil will about 150 milliard dollars.

In a feasibility study made by the financier Waled Abo Slieman, showed that Lebanon can generate about 2.3 milliard of dollars each year from oil and gas in the worst cases. This can make a big shift in the Lebanese economy and help Lebanon to repay its debt, balance its balance of payment, decrease unemployment and animates the dead economy specially the industrial and agricultural sectors after the cost of production will be lower.

However, the problem is that, process to start extracting oil and gas and start to generate the funds need minimum 7 years even if all the political and security situations were stable and fine. Here comes the role of government to accelerate the process as much it can be accelerated to save the financial condition that may not hold till that time.

\section{The merciful bailout}


The bailout of debt, the merciful of God, an act of giving financial support to a country that faces serious financial difficulty or bankruptcy or simply it can be a forgiveness of a certain amount of debt. But scarcely the countries forgive on their lending, and it depend on powerful of the politicians and governments and their international relationships specially with the countries from where they borrowed, more over the governments should be loyal for the courtiers that forgive it on its debt, nothing will be for free. The bailout given under condition to be satisfied as political, economical or financial conditioning some can be declared officially such as economical and financial condition, or undeclared officially such as political conditioning.

Greece for example get out from its debt crisis by a bailout, that's when the Euro zone countries and the International Monetary Fund (IMF) agreed on a $€ 110$ billion bailout loan for Greece.

However, conditional on compliance with the following three points, the Implementation of austerity measures to restore the fiscal balance, the privatization of government assets worth $€ 50 \mathrm{bn}$ by the end of 2015 to keep the debt pile sustainable, and implementation of outlined structural reforms to improve competitiveness and growth prospects.

Here comes the role of politicians to try to get some bailouts of debt that can decrease the total national debt and thus decrease the service of debt that is responsible to decrease the national deficit. So in Lebanon a politician party should go west and the other party should go east and let's see which one is stronger in bailing out the debt of Lebanon, and thus let them compete on something that serve Lebanon not something that macerate it.

\section{Battering corruption}

The last point that I can explain as a way to decrease the national debt and the deficit, is the corruption that is controlling all sectors in Lebanon without any exceptions, Lebanon's public sector ranked 127 among the most corrupt countries, an international watchdog group said in its annual survey. Transparency International's 2013 Corruption Perceptions Index scored 177 countries and territories on a scale from 0 (highly corrupt) to 100 (very clean). Lebanon scored 28 this year while the country scored 30 in its Corruption Perceptions Index for 2012, which indicates a slight rise in corruption.

Lebanon is a fertile land for corruption. It is more than a way of life. Life doesn't function in Lebanon without corruption. You want to get a driver license without taken a test, bribe someone. You want to build a building illegally, all you have to do is bribe someone. You want to import expired food to the country, just bribe someone. You want to get elected in the next elections (any election) just buy some votes.

Corruption in Lebanon exists in all its forms including bribery, nepotism, favoritism, patronage, embezzlement, kick-backs, and vote-buying. The Lebanese system prevents control and penalization. The culprits are protected by their respective communities and leaders, everyone gets a cut and national interest doesn't exist in Lebanon dictionary. Corruption in Lebanon costs around $10 \%$ of its GDP, so between 4 to 5 milliard dollars is the approximated yearly cost of 
corruption in Lebanon which means around $\$ 1,000$ per Lebanese citizen as a cost paid yearly.

Lebanese must tackle the culture of corruption that is rooted in the society. Whistle-blower protection law and a freedom of information act should be passed in order to provide much-needed transparency for official government action. Moreover, the legislations of new effective law against corruption is needed to be activated and strapped, the Organizations that fight corruption need to be supported and encouraged, the penalization must be enforced for any corruption case. The lawmakers are part of this corruption culture of ours, in order to defeat corruption, you need to have the right people in the right place, and the battle against corruption starts in electing people who are ready to fight corruption.

\section{Conclusion}

Finally as a conclusion, we can state that the Lebanese financial condition is miserable. The national debt is increasing to horrible levels, and the deficits in government is increasing and expected to increase in the subsequent years since the government spending is increasing without any deterrent in the time the revenues to the government are decreasing. That's because of bad economic and political conditions, higher demand on necessity imports such as fuel, and tax evasion and corruption. In addition, the inflation rates are increasing and the economic growth is decreasing.

These conditions are decreasing the ability of the government to repay its debt or at least pay its service, increasing the pressures on Lebanese pound and threatening its value. With all the assures from Lebanese central bank governor and the financial officers, a prudent man can sense the risk that is coming on the Lebanese pound and never believe that the Lebanese pound will stay forever the mountain that never lean with wind. Lebanon must take rapid corrective actions to safe the country and its currency from a disaster that would howl in Lebanon same as it howled in Argentina, Bolivia before and Greece recently; or the periodic wheal will get us back to 1980s when the Lebanese pound collapsed.

Corrective actions come from balancing the balance of payment equation, through boosting the exports and taxes on one side, and on the other side decrease the imports and spending. Boosting the exports starts from stimulating the industrial and agricultural sectors in Lebanon, encouraging the industrial sector by offering tax exemptions, lower interest rates on any borrowings for these sectors, legislating laws that protect the Lebanese industrial products and encourage professional education that is necessary to create the labor force that needed for such industries. On the other hand, stimulating the agricultural sector by jettison the static thinking and be open for new agricultures to be exported such as hashish and crocus which is known by red gold.

In addition to giving low interest rate loan to back this sector, encourage the use of technology in agriculture, legislating laws that protect the Lebanese products, increase the tariff taxes on imported agricultural products.

Moreover, Lebanon should think about rising taxes and cutting the spending through active austerity programs to keep savings to serve the national debt. However, the increase in taxes not necessarily on VAT, it could be on corporate 
tax on profit, tax on movable capital, property tax, luxuries, alcohols, tobacco products, entertainments, new cars, luxury food, This can keep balance between social layers and increase retains for government.

After thinking about the direct for elements of the balance of payment, we can think about other ways to solve the deficit and thus safe the Lebanese pound. These ways such as privatization that can make governmental organizations more effective and efficient, rebalance the Lebanese economy, encourage investments and stimulate Beirut bourse. In Lebanon to have successful privatization we need effective financial market to under write the issue and we need new legislations to organize the process. Privatization proved its efficiency in Greece to be solution to get out from national debt.

In addition, now days we can think about starting to depend on the natural resources to produce power such as the hydropower, wind power and solar power. Lebanon owns all capabilities from water, active wind movements and sun hours to start this procedures, but government is semi absent about such opened opportunities knowing that $70 \%$ of electric power costs can be reduced. In addition to such renewable resources, recently non-renewable resources of oil and gas discovered in Lebanese water that are capable to promote the Lebanese economy and simply kill the debt ghost.

On the other hand, the bailout can be solution when the government finds no solution to decrease its debt, Lebanon should be ready to satisfy conditions or donate political or economical privileges were Lebanon have experience in such domain.

The last step that we can make is to fight corruption that is howling in Lebanon without any penalizations and deterrents, and that costing Lebanon to much every year. Whistle-blower protection law and a freedom of information act should be passed in order to provide much-needed transparency for official government action. Moreover, the legislations of new effective law against corruption is needed to be activated and strapped, the Organizations that fight corruption need to be supported and encouraged, the penalization must be enforced for any corruption case.

These ways are increasing exports and taxes and decreasing imports and spending, privatization, using natural resources for electric power, bailout and fighting corruption; all are capable to generate more fund for the government treasury and make the balance of payment positive and thus protect the Lebanese pound that band the Lebanese people together and we should sacrifice to protect it.

\section{References:}

Nader, S (2014, March 21). Lebanon needs drastic steps to avoid bankruptcy. Retrieved from: http://www.al-monitor.com/pulse/originals/2014/03/lebanon-public-debt-bankruptcy-threat.html

Trading economics (copy right 2017). Lebanon Government debt to GDP. Retrieved from https://tradingeconomics.com/lebanon/government-debt-to-gdp

Republic of Lebanese ministry (2017, May). General debt overview. Retrieved from http://www.finance.gov.lb/en-US/finance/PublicDebt/Pages/default.aspx

Choueiri, F. , Zaarour, M. , Hasidar, J. , Samaha, J. \& Gergi, J. ,( 2016, July). Dissecting the Lebanese public debt: Debt dynamics \& reform measures. Retrieved from 
https://www.creditlibanais.com.lb/Content/Uploads/LastEconomicAndCapitalResearch/1607111 12203804.pdf

Wikimedia foundation, Economy of Lebanon (2017 August) , Retrieved from https://en.wikipedia.org/wiki/Economy_of_Lebanon

Lebanon national debt (2015), Retrieved from http://countryeconomy.com/national-debt/lebanon

Lebanon economy, Lebanon GDP and national debt, retrieved from http://countrymeters.info/en/Lebanon/economy

CIA World factbook (2017,JULY), Lebanon public debt, retrieved from http://www.indexmundi.com/lebanon/public_debt.html

Mikhael, M. , Daou, R. (2015, June 06). Debt sustainability analysis for Lebanon 2015-2020, BLOMINVESTMENT bank. Retrieved from: http://blog.blominvestbank.com/wpcontent/uploads/2015/06/Debt-Sustainability-Analysis-for-Lebanon-2015-20201.pdf

CIA World factbook (2017,January), Lebanon economy 2017, Retrieved from http://www.theodora.com/wfbcurrent/lebanon/lebanon_economy.html

Republic of Lebanon (2016), Agriculture fact book, retrieved from http://investinlebanon.gov.lb/en/sectors_in_focus/agriculture

Ministry of Agriculture (2014, November), Ministry of Agricultural strategy 2015-2019, Retrieved from http://www.agriculture.gov.lb/Arabic/NewsEvents/Documents/MoA\%20Strategy\%20201519\%20-\%20English-for\%20printing.pdf

Economy watch (2010,March 29), Lebanon industry sectors, Retrieved by http://www.economywatch.com/world_economy/lebanon/industry-sector-industries.html

Nacouzi, F. (2004, June 28), Lebanon Industrial sector faces challenges, Daily stars, Retrieved by http://www.dailystar.com.lb//Business/Lebanon/2004/Jun-28/1479-lebanons-industrial-sectorfaces-challenges.ashx

Association of Lebanese Industrialists (2015, March), The state of Lebanon's Industry, Retrieved by http://www.ali.org.lb/news/state-lebanons-industry

Republic of Lebanon, Ministry of finance, (2001, December), Value added tax law, Retrieved by http://www.databank.com.lb/docs/VAT.pdf

The World Bank, Doing business, Paying taxes in Lebanon, Retrieved by http://www.doingbusiness.org/data/exploreeconomies/lebanon/paying-taxes

Trading economics (2017), Lebanon government spending, retrieved by https://tradingeconomics.com/lebanon/government-spending

Trading economics (2017), Lebanon government spending forecast 2020, https://tradingeconomics.com/lebanon/government-spending/forecast

UNDP (2013), CEDRO Exchange Issue number 3, retrieved by http://cedroundp.org/content/uploads/Publication/141009092004589 Exchange\%203.pdf

UNDP (2013, February), CEDRO Exchange Issue number 4, retrieved by http://www.progreendiploma.com/wp-content/uploads/2017/03/Hydropower-in-Lebanon-1.pdf

Macropolis (2010, June 7), Lebanon Report, Lebanon Privatization, Retrieved by http://www.marcopolis.net/lebanon-privatization.htm

Sabbagh, N. (2014, June 4), Lebanese government to push for privatization of public utilities with World Bank cover, AlAkhbar news, Retrieved by http://english.al-akhbar.com/node/20030

Middle East business news and events (2017, January 5), Lebanon to become an oil and gas producing country. Retrieved by http://www.ifpinfo.com/Lebanon-NewsArticle-8276

http://www.business-anti-corruption.com/country-profiles/lebanon

Trading economics (2017), Lebanon corruption rank, Retrieved by https://tradingeconomics.com/lebanon/corruption-rank. 